\title{
Regional Approaches to Better Standards Systems
}

\author{
Enrique Aldaz-Carroll ${ }^{1}$
}

\begin{abstract}
Developing countries face an increasing need to upgrade the standards of their domestic markets and of their exports. This paper examines different approaches available to them for upgrading their standards and conformity assessment procedures. It focuses particularly on those followed within the context of regional trade agreements (RTAs), as these are yielding promising results. Based on interviews performed in Latin America and on previous literature, the paper draws common features of a RTA standard and conformity assessment upgrading and harmonization process, identifies some of its main challenges and suggests principles that developing countries could follow in such a process.
\end{abstract}

Keywords: standards, conformity assessment procedures, harmonization, upgrading, regional trade agreement.

\section{World Bank Policy Research Working Paper 3948, June 2006}

The Policy Research Working Paper Series disseminates the findings of work in progress to encourage the exchange of ideas about development issues. An objective of the series is to get the findings out quickly, even if the presentations are less than fully polished. The papers carry the names of the authors and should be cited accordingly. The findings, interpretations, and conclusions expressed in this paper are entirely those of the authors. They do not necessarily represent the view of the World Bank, its Executive Directors, or the countries they represent. Policy Research Working Papers are available online at http://econ.worldbank.org.

\footnotetext{
${ }^{1}$ Email: ealdazcarroll@worldbank.org. This paper was written as a Background paper for the Global Economic Prospects 2005: Trade, Regionalism and Development, World Bank, Washington, D.C. The author would like to specially thank Paul Brenton for his very helpful suggestions and comments and all those who provided useful comments on the paper; particularly Manuel Olarreaga, Fredy Núñez, Reinaldo Figueiredo, Richard Newfarmer, Mirvat Sewadesh, Fernando Hernandez, Barbara Kotschwar, John Wilson, Steve Jaffee and Manuel Albaladejo; as well as the interviewees for their time.
} 
"The real $21^{\text {st }}$ century trade issues are standards and rules in areas such as safety, health or consumer protection” (Pascal Lamy, EU trade commissioner, Financial Times 9/9/2004)

\section{Introduction}

Developing countries are experiencing an increasing need to upgrade standards in their domestic and export markets. The need for higher standards requirements in their domestic market is caused by the surge in imports to developing countries resulting from their greater liberalization. This surge is raising developing countries' concern about ensuring that imported products are safe for consumers and the environment. Such is the case for instance in Peru, which is experiencing a great influx of low quality Chinese manufactured goods. The need for higher export standards originates from the rising standards requirements in developed countries’ markets.

This paper examines different approaches available to developing countries in upgrading their standards and conformity assessment procedures, focusing particularly on approaches followed within the context of regional trade agreements (RTAs), as these are yielding promising results. Based on RTAs' upgrading experiences, the paper makes suggestions for a more effective upgrading implementation process.

There are different paths available to upgrade standards. Upgrading standards unilaterally to international levels is the simplest process, but can prove costly for countries in a low development stage. The cost these countries must incur to readjust their production and regulatory structures to meet international standards is significant, yet the returns are not always ensured since the satisfaction of international standards does not guarantee market access. If the upgrading is not coordinated with trading partners, the upgrade might not be high enough to meet partners' new standards and conformity assessment requirements. To minimize this problem many countries have upgraded their standards following a coordinated harmonization process with other trading partners.

The type of coordinated path that a country can follow depends on the institutional sophistication of the trade agreement that the country has with the partners with which it is coordinating its upgrading. Two distinct coordinated approaches are the cooperation approach and the RTA approach. The cooperation approach is that followed by bilateral trade agreements and by multilateral cooperative agreements, like APEC. It has less enforcement power than an RTA approach, and can therefore encounter greater obstacles if some members are not fully committed to the upgrading process. An RTA approach is that followed by the members of an RTA and it involves not only the upgrading of standards, but also the regional harmonization of standards.

Two types of RTA approaches to standards upgrading can be identified based on the speed at which the regional standard is upgraded to the international standard and will be the ones this paper focuses on. The first is the one go approach: member countries 
regionally harmonize and upgrade their standards for the selected product at once, equating the regional standard to the international standard. This approach is followed by RTAs like the Association of South-East Asian Nations (ASEAN),

The second approach is the gradual upgrading approach: member countries upgrade their standards gradually towards the international standard rather than immediately. This approach tends to be followed by RTAs with members that have a technological level or health, security and environment objectives that are not aligned with international standards. Such is the case of the Andean Community and Mercosur. In order to guarantee market access as standards rise, member countries coordinate their upgrading by regionally harmonizing their standards towards a certain intermediate level. Exports satisfying this intermediate standards level are guaranteed market access to member countries' markets.

To date, RTAs in the developing world have not begun to realize their full potential for overcoming standards related obstacles to regional or global trade. Though there is yet no clear best practice, it is possible to draw some common principles from RTAs' past experiences and from existing literature for a more effective upgrading and harmonizing process of standards and conformity assessment procedures: prioritize sectors for reform; build trust between RTA members; set a quality regulation based on simplification, transparency and dynamism; allow for gradual reform if needed; build regulatory capacity; and promote mutual recognition of conformity assessment procedures.

This paper aims to contribute to the scarce literature on regional approaches to standards upgrading. It complements Kotschwar's (2001) review of standards in Latin American RTAs and Xiaoyang-Chen and Mattoo's (2004) assessment of the impact of regional standards agreements on trade by employing information obtained through interviews to draw lessons from RTAs' experiences on standards upgrading. The interviews were conducted with representatives of firms, business associations, laboratories, accreditation bodies, standardization bodies, and national and regional bodies of TBT and SPS standards in Argentina, Brazil, Chile, Peru, Uruguay, and Washington DC.

The paper is structured as follows. Section 1 briefly presents standards and conformity assessment procedures. Section 2 reviews the unilateral and coordinated approaches to standards upgrading. Section 3 examines RTA standards upgrading and harmonizing experiences and derives some common features. Section 4 presents principles that can guide developing countries in the process of regional upgrading and harmonizing of standards and conformity assessment procedures and suggestions for a more effective participation in the international standards arena. The last section concludes.

\section{STANDARDS, CONFORMITY ASSESSMENT AND DEVELOPING COUNTRIES}

A standard outlines the special characteristics of processes, products, or services. Standards facilitate trade since they "stipulate what can or cannot be exchanged and define the procedures that must be followed for exchange to take place" (Brenton 
2004:1). Thus complying with standards requirements in foreign markets is a critical factor determining market access to those markets. ${ }^{2}$

Standards can be of a voluntary or compulsory nature. A technical regulation is a compulsory standard imposed by a government at the local, regional or national level to secure health, safety, and environmental and consumer protection. A technical regulation for instance can specify the limit of car exhaust emission levels. A voluntary standard is a market driven standard that "reflects the demands and tastes of consumers or the technological requirements of industrial purchasers" (Brenton 2004:1). A voluntary standard for instance specifies the type of knobs used in a car. Note that while the satisfaction of a voluntary standard is legally voluntary, it is de facto necessary to secure sales since most voluntary standards are enforced by the market (Hufbauer, Kotschwar and Wilson 2001). It would therefore be more accurate to name these two types of standards public and private standards, but we will follow convention and refer to them as technical regulations and voluntary standards.

The conformity assessment process involves those procedures that ensure that a firm's product (service) satisfies the specifications set in a standard. It encompasses one or more of the following procedures (Wilson 1995): testing (a manufacturer's declaration of conformity through testing conducted on its own laboratory or a third party laboratory), inspection (independent inspection of parts, materials and final products), certification (formal certification by a third party that a product conforms to particular standards, which often includes the granting of mark, certificate or label), registration (independent audit of manufacturing quality systems that results in registration with a quality systems registrar, i.e., ISO 9000 or ISO 14000), and accreditation (evaluating and attesting that testing and calibration laboratories, certification bodies and inspection bodies are technically competent to perform a specified task).

There are two main differences between tariffs and standards and conformity assessment procedures. The first difference is their objective. The objective of tariffs is to limit trade, whereas the ultimate objective of standards and conformity assessment is to facilitate trade by protecting health, safety and the environment, and by improving productive efficiency. When these legitimate objectives are satisfied, standards serve a public goal and their removal is undesirable since they correct a market failure. Such market failure can arise from invisible health and safety attributes of products, negative environmental externalities, or incompatibility between products because of lack of coordination between producers. Tariffs, however, are always trade barriers and create therefore a distortion. Standards and conformity assessment are only trade barriers when differences in voluntary standards, technical regulations or conformity assessment procedures across countries are not justified by the legitimate objectives they aim to fulfill or when they are not publicized. The second difference is that tariffs are a static measure, whereas standards and conformity assessment are dynamic measures. They are dynamic because they need to evolve as technology and consumer requirements for product quality and safety change over time.

\footnotetext{
${ }^{2}$ See Swan, Temple and Schumer (1996) and Jaffee and Henson (2004) for an analysis of the positive effect that standards can have on export performance.
} 
Differences across countries in standards and conformity assessment increase transaction costs leading to less trade. When domestic and foreign standards and conformity assessments do not coincide, double costs are imposed on the producers catering for domestic and export markets since they must produce the product under two different standards and the product has to be subject to testing at origin and destination. These costs are further aggravated if different trading partners have different standards. For example, representatives of the US industry claimed that meeting the EU's tests for telecommunications equipment takes

six to eight weeks, reducing product value by five to ten percent (USITC, 1998, 4-2)[...] [D]uplication of mandatory U.S. and EU testing for computers, telecommunications equipment, and similar IT products raised costs for U.S. companies by more than $\$ 1.3$ billion annually (USITC,1998, 4-8). Finally, some importing nations require compliance with specific norms that duplicate international standards, raising an additional and unnecessary testing cost (Maskus, Wilson, Otsuki 2001:23).

The OECD (1996) found that in the case of small firms in developing countries differing standards and technical regulations between markets, combined with the cost of testing and compliance certification, could constitute between two and 10 percent of overall production costs - not an insignificant amount (Kotschwar 2001:142). A 1993 study commissioned by the Australian Minister for Trade

on the extent to which standards could represent a non-tariff barrier to trade in the APEC region concluded that a modest liberalisation of trade restricting standards could increase regional trade by possibly 20 per cent, which represents an increase of about 3 per cent to regional GDP (Andison 1996:1).

The case of pallets illustrates the distortionary effects of differences in standards across countries (see Box 1). 
Box 1: Proliferation of standards increases trade costs and can lead to proliferation of standards in other sectors: the case of pallets.

The case of pallets illustrates the impact of non-harmonization of standards on trade. It is a particularly interesting case because of the many different pallet standards and the prevalent use of pallets -80 percent of freight containers leaving the US contain products that are stored in pallets.

The pallet is a portable, horizontal, rigid platform used as a base for storing, staking, handling, and transporting goods as a unit load (National Wooden Pallet \& Container Association 2004). The development of the pallet was one of the two key innovations for storage and distribution of the twentieth century (Le Blanc 2002). It was developed in the 1930s in the US to protect the product, improve storage and make distribution more efficient. Its use spread rapidly to the rest of the world. However, as transport companies in other countries adopted the pallet, many employed pallets with different standards. At present, there are thousands of different pallet standards active in the world: pallets vary in size, composition, and potential health and environment hazard.

This multiplicity of standards diminishes the efficiency of distribution that the pallets were initially designed for. If the destination country refuses entry of pallets that do not satisfy a particular standard or the local machinery cannot work with pallets that do not satisfy a particular standard, the goods have to be manually transferred to a pallet that satisfies that standard. This increases the cost of handling, extends transport time, leads to greater losses due to damaged goods, and causes the additional cost of having to rent different pallets depending on the market of destination. Even when the destination country accepts entry of pallets of different standards, the use of different pallet sizes leads to poor container space use and increases trade costs. A European study conducted by AT Kearney concluded that "current pallet heights make poor use of vehicle inner heights... as a result, $15 \%$ additional grocery trucks are required" (Penman 1997:6). The space that would be saved loading standardized pallets into containers can represent 1.2 percent of the retail sales price. The multiplicity of standards increases trade costs for all countries and is particularly challenging for developing countries. Developing countries' lower access to pallet rental markets grants them less flexibility to satisfy trading partners' pallet requirements.

While there are legitimate environmental and phytosanitary reasons why some countries apply stricter standards, there appears to be no legitimate justification for having many different pallet sizes. The ideal solution would be the harmonization of pallet sizes. This has proven to be a daunting challenge because regions employ different pallet sizes and are reticent to abandon them. To make matters worse, the nonharmonization in the pallet sector appears to be leading to diversity in previously harmonized sectors. Though the European Commission is complaining about the diversity of standards, it is trying to create diversity of standards in the field where standardization is the most widespread worldwide: containers. Since the Europallet fits very badly in the standard ISO container, the EU is developing a new container, the EILU, with a larger size. Such move will break away from the harmonized container standard and increase transport costs for the rest of the world.

Note: See Raballand and Aldaz-Carroll (2005) for more details.

To reduce transaction costs associated with differences in standards a number of international standards bodies (like ISO and IEC) have elaborated international voluntary standards and are encouraging countries to harmonize their standards with these international standards. The harmonization of standards in the electronic industry for instance has allowed for greater interoperability between products reducing production costs and allowing for greater fragmentation of production between countries. The harmonization of terminology and product definitions in other sectors has also diminished transaction and information costs. 
Developing countries are generally characterized by a weak standardization culture. Products tend to be produced with little emphasis on the satisfaction of standards and consumers are typically less inclined to complain or return products that are unsafe or have defects. Examples of this are the Peruvian import of Chinese sweets with incomplete translations of their labeling (which poses a risk for people with allergies) or the sale in some African countries of processed food after their expiry date (see Box 2).

\section{Box 2: Weak standardization culture in developing countries}

An illustrative example of the weak standardization culture in developing countries can be seen in the office of a director in the Ministry of Industry in a Latin American country. As pointed out by the director, the office had three doors with different dimensions, eight window panels with different widths and a table with a different height and composition to that of other offices. This purposeless asymmetry increases replacement costs and limits economies of scale in the production of such products.

However, since the late nineties there has been an increasing interest among developing countries in product standards. There have been efforts on the part of standardization bodies and governments to improve the standardization culture among firms and consumers through awareness campaigns and the promotion of standards setting.

Standards upgrading can help developing countries assimilate foreign technology, increase demand and export quality and reduce transaction and production costs. For example, Vietnam upgraded its motorbike standards to ISO standards and later graduated to higher standards increasing its competitiveness in this product. Improvements in the meat sector in Uruguay allowed it to enter the US organic meat market and get a 30\% higher price. ${ }^{3} \quad$ Meeting international standards secured market access to Peruvian asparagus producers in the EU (Jaffee and Henson 2004).

LDCs are increasingly being left out from the benefits of greater integration between developed countries. The recent regional standards agreements between developed countries have increased intra-regional trade and exports of excluded developed countries into these regions, but have reduced exports of developing countries into these regions (Xiaoyang-Chen and Mattoo 2004). A possible reason for this, argue Xiaoyang-Chen and Mattoo, is that developing country firms are more hurt by the increase in the stringency of standards that results from these regional standards agreements and therefore benefit less from economies of scale in that integrated market. Standards upgrading will enable developing countries to benefit from the greater integration between developed countries.

The setting of higher standards can impede trade if they are motivated by protectionist sentiment and are applied in a discriminatory fashion against imports. This concern led the World Trade Organization (WTO) to set up the framework for product health, safety, and environmental regulations through the Agreements on Technical Barriers to Trade (TBT) and Sanitary and Phytosanitary standards (SPS). The TBT and SPS frameworks

\footnotetext{
${ }^{3}$ Note, however, that sale costs also increased due to the higher cost of getting an organic certification.
} 
establish the guidelines to be followed so that the setting of standards is not performed with protectionist intentions. These agreements regulate voluntary standards, technical regulations and conformity assessment activities. They do not cover services and do not apply to government procurement activities. They are obligatory for all WTO members, though are not yet strongly enforced.

The SPS Agreement covers all measures whose purpose is to protect: human or animal health from food-borne risks; human health from animal- or plant-carried diseases; or animals and plants from pests or diseases. The TBT Agreement covers all technical regulations, voluntary standards and the procedures to ensure that these are met, except when these are sanitary or phytosanitary measures as defined by the SPS Agreement. ${ }^{4}$

The six main principles of the TBT and SPS rules are:

1- Non-discrimination requirement.

2- Proportionality requirement: regulations must not be more burdensome than necessary.

3- Regional and national standards should be based, to the greatest extent possible, on international standards.

4- Sanitary regulations must be based on available scientific evidence.

5- Countries are encouraged to recognize each other's standards and testing procedures as equivalent - i.e. if two countries have different ways to fulfill the same objective, they should accept each other's ways of fulfilling it.

6- Enhance the exchange of information among the member governments and increase transparency in the standards-setting process.

With regard to transparency and information systems, countries are required under the WTO TBT arrangement to establish enquiry points or centers of information to answer queries and provide relevant documentation in a timely and cost-effective manner. Most of the RTAs in the Americas have established enquiry points and encourage member countries to make notifications concerning standards-related measures (Kotschwar 2001).

The TBT and SPS disputes are becoming more prominent in WTO disputes. During the first five years of operation of the WTO's Dispute Settlement Understanding (DSU), 25 cases (13 percent of the total) referenced standards-related provisions (Kotschwar 2001).

\section{DIFFERENT APPROACHES TO THE UPGRADING OF STANDARDS AND RECOGNITION OF CONFORMITY ASSESSMENT PROCEDURES}

This section will first examine different approaches to standards upgrading and will then examine different approaches to the recognition of conformity assessment procedures.

\footnotetext{
${ }^{4}$ Taken from http://www.wto.org/english/tratop_e/sps_e/spsund_e.htm
} 


\subsection{UNILATERAL AND COORDINATED APPROACHES TO STANDARDS UPGRADING}

Drawing from countries' experiences, two main approaches to upgrading standards can be identified: unilateral and coordinated (see Figure 1). In the unilateral approach a country upgrades its standards for a product or products by unilaterally adopting the international standards. The main positive aspects of adopting international standards are: first, it provides a positive signal to buyers that the country in general has a "standards culture." Second, since international standards are recognized by the TBT and SPS agreements, adopting these standards provides legitimacy to the country adopting them. The country's standards would automatically be presumed to be consistent with the WTO agreements. Lastly, adhering to international standards may facilitate market access to other countries.

Figure 1: Different approaches to standards upgrading and harmonizing

Unilateral: unilateral adoption of international standards (e.g. Chile).

Coordinated: countries coordinate their standards upgrading

Cooperation approach: low levels of enforcement and of formal institutions. Objective can be standards harmonization (e.g. APEC) or standards compatibility (e.g. Chile-USA).

RTA approach: higher degree of enforcement and of formal institutions. Regional standards harmonization between RTA members. Different upgrading speeds:

- Upgrading in one go to international standards (e.g. ASEAN)

- Gradual upgrading towards international standards (e.g. Andean Community and Mercosur).

There are two potential shortcomings to this approach: the first is that the technological content and the health, security, and environment objectives of the international standard may not be aligned with the country's development stage since the international standards are generally set by the OECD countries. In countries where differences in objectives are marked and where the domestic market is small the readjustment costs of upgrading to international standards is high and the potential benefit for the domestic economy is low due to small economies of scale. Such countries might consider setting different standards for the domestic market and the export sector.

The second potential shortcoming is that WTO regulations on standards are not yet compulsory. Thus, the returns - in terms of greater market access - to adopting the international standard only materialize if the country's trading partners accept products produced at the international standard. The satisfaction of an international standard is not a guarantee of market access into the OECD markets, to name just one example. In these markets the requirement to satisfy additional voluntary standards is becoming more prevalent - e.g. some EU supermarkets require that imports satisfy the voluntary standard EUROGAP, which stipulates good farming practices that suppliers must adhere to.

The second type of approach is the coordinated approach, which entails coordination between countries. To guarantee positive returns in terms of market access to the costly 
process of standards upgrading, a group of countries can cooperate with each other to ensure that products reaching a particular standard level (which is not necessarily the international standard level) will be accepted in each others' markets.

Two distinct coordinated approaches have been followed: the cooperation approach and the RTA approach. The cooperation approach is that followed by bilateral trade agreements, like Chile-USA, and by multilateral cooperative agreements, like APEC. This approach involves less formal institutions and lower levels of enforcement and of trust between members than the RTA approach. Since the cooperation approach (bilateral and multilateral) does not entail the elimination of tariffs between members, a member can resort to greater tariffs to prevent entry into a particular sector even though imports satisfy the agreed standards level. In countries where tariffs are bounded at levels close to the applied levels, the risk of tariff increases is less and thus the likelihood of standards harmonization succeeding is greater. This explains to some extent why the EU and ASEAN have agreed to start harmonizing standards in agriculture and three other sectors between the two regions as a first step towards negotiating a trade agreement (Financial Times 9/9/2004). The two regions are able to start by harmonizing standards rather than tariffs because their tariffs are already bounded at low levels, which limits their ability to increase tariffs to prevent entry of products satisfying the harmonized standards.

Another limitation of the cooperation approach is that the dispute panels have a mediation role not an arbitration role. For these reasons, unless all parties are committed to the upgrading process, the process of standards upgrading could be faced with important obstacles.

The ultimate objective of the cooperative approach can be standards harmonization, as in APEC, or standards compatibility, as in most bilateral trade agreements (see Table 1). The difference between standards harmonization and standards compatibility is that the latter implies members must change their standards only to the extent necessary for compatibility to be possible, whereas harmonization seeks making members' standards the same. 


\begin{tabular}{|c|c|c|c|}
\hline Agreements & Policy objective & $\begin{array}{l}\text { Compatibility } \\
\text { and equivalence }\end{array}$ & $\begin{array}{l}\text { Right to } \\
\text { establish level } \\
\text { of protection }\end{array}$ \\
\hline WTO & Harmonize & No & No \\
\hline \multicolumn{4}{|l|}{ Customs unions } \\
\hline Andean Community & Harmonize & No & No \\
\hline ASEAN & Harmonize & No & No \\
\hline Central American Common Market & Harmonize & No & No \\
\hline CARICOM & Harmonize & No & No \\
\hline EU & Make compatible/harmonize & Equivalence & No \\
\hline MERCOSUR & Harmonize & No & No \\
\hline \multicolumn{4}{|l|}{ Free trade agreements } \\
\hline APEC & Make compatible & Yes & Yes \\
\hline NAFTA & Make compatible & Yes & Yes \\
\hline Group of Three (Mexico, Colombia \& Venezuela) & Make compatible & Yes & Yes \\
\hline Free Trade Area of the Americas (FTAA) & Make compatible & Yes & Yes \\
\hline Bolivia-Mexico & Make compatible & Yes & No \\
\hline Chile-Mexico & Make compatible & Compatibility & Yes \\
\hline Costa Rica-Mexico & Make compatible & Yes & Yes \\
\hline México-Nicaragua & Make compatible & Yes & Yes \\
\hline Mexico-Northern Triangle & Make compatible & Yes & Yes \\
\hline Central America-Chile & Make compatible & Yes & No \\
\hline Central America-Dominican Republic & Make compatible & Yes & No \\
\hline CARICOM-Dominican Republic & Make compatible & Yes & No \\
\hline
\end{tabular}

Note: The Canada-Chile agreement does not address technical barriers to trade.

Source: Based on Kotschwar (2001).

The second type of coordinated approach is the RTA approach, which is the approach followed by RTAs to upgrade standards. It seeks to harmonize member countries' standards regionally either by upgrading standards in one go and equating them to the international standards or by setting regional standards and gradually upgrading them towards the international standard. This approach is characterized by more formal institutions, a higher degree of enforcement and greater trust. Such trust originates from the more frequent interactions between members and the more comprehensive nature of the agreement, which allows for the possibility of cross-issue retaliation. Due to the elimination of intra-regional tariffs, RTA members cannot use tariffs to prevent the entry of a product satisfying the regional standard, hence increasing the certainty that a country's upgrading efforts will be translated into greater market access.

The RTA approach is increasingly being used by developing countries as a path to upgrading standards - e.g. Andean Community, Mercosur, and ASEAN. It is for this reason that the rest of the paper focuses on this approach.

\subsection{DIFFERENT APPROACHES TO THE RECOGNITION OF CONFORMITY ASSESSMENT PROCEDURES}

The success of a regional standards harmonization process in terms of greater regional trade and market access crucially depends on a country's conformity assessment procedures being recognized by the other member countries: recognition of test data, product certification and competence of accredited conformity assessment bodies. 
Otherwise, companies are obliged to perform additional or repeated tests of their products overseas or to invite foreign inspectors, increasing costs.

There are different approaches to integrating members' conformity assessment procedures. The WTO TBT Agreement aims to prevent conformity assessment procedures from becoming trade barriers and favors their harmonization as a channel to promote greater integration. This contrasts with the EU position, which does not consider harmonization as its axis for greater integration.

The EU's approach to integrating members' conformity assessment procedures does not require full legislative uniformity or full centralization of supervision. It is based on the mutual recognition agreement (MRA). This consists of mutual recognition of national laws (e.g. technical regulations), harmonization of national legislation only when mutual recognition is unworkable, ${ }^{5}$ prevention of new barriers by establishing compulsory information mechanisms, and mutual recognition of conformity assessment procedures. The latter is achieved by developing transparent criteria to determine when conformity assessment procedures should be considered comparable. The MRAs are envisaged in the field of conformity assessment procedures for industrial products, based on the "once tested accepted everywhere principle”. Country A trusts country B to certify that the products made by B satisfy the standards requirements of A. The reliance on mutual recognition of both standards and conformity assessment even when harmonization is incomplete is what has allowed the successful establishment of the Single Market in highly regulated service industries like banking and insurance. ${ }^{6}$ According to 2001 estimates, $21 \%$ of industrial production inside the EU is covered by mutual recognition and about $28 \%$ of intra-EU manufacturing trade (Commission of European Communities 2001). It is estimated that ensuring the perfect operation of mutual recognition inside the EU would produce a maximum possible one-off increase in EU's GDP of 1.8\% (Commission of European Communities 2001).

The EU has extended the concept of mutual recognition beyond the EU market and has been signing MRAs with some of its trading partners (among others, United States, Canada, Australia, New Zealand, Switzerland, Israel, and Japan). The 1997 MRA between EU and USA was estimated to remove barriers on \$40 billion worth of trade between both parties, and to eliminate up to $80 \%$ of compliance and testing costs. ${ }^{7}$ The EU-US MRA was estimated to reduce direct costs to IT firms by $\$ 1.3$ billion and to shrink approval periods and raise competition among testing laboratories (USITC, 1998, 5-3 quoted in Maskus, Wilson, Otsuki 2001:26).

\footnotetext{
${ }^{5}$ For example, homogenous certification structures have been created throughout Europe to generate confidence in testing and certification conducted abroad.

${ }^{6}$ A product satisfying a standard in the originating member country which is different to the standard of the destination member country will be allowed entry into the latter member's market as long as it satisfies the minimum equivalence conditions. Similarly, the destination member country will recognize the certification of the originating member country even if their conformity assessments are not equal so long as the conformity assessments of the two countries are comparable.

${ }^{7}$ An estimate performed before its implementation in 1997 reported in García Jiménez and Gardeñes Santiago (1997). A similar value is reported by Maskus, Wilson and Otsuki (2001).
} 
As noted by Xiaoyang Chen and Mattoo (2004), a key element of the MRA is the rule of origin, which determines where the product was made and therefore, the treatment the product receives. Not all MRAs have the same rule of origin restrictions:

The MRAs between the EU and USA and the EU and Canada specify that conformity assessment done in one of the MRA countries, in which products are manufactured or through which they are imported, is accepted throughout the entire agreement region. Other agreements, such as the MRAs the EU has concluded with Australia and New Zealand, impose restrictive rules of origin which require that third country products continue to meet the conformity assessment of each country in the region (Xiaoyang Chen and Mattoo 2004:4).

The impact of MRAs on third country's exports to the region depends on whether they include rules of origin. This can have important implications for developing countries. According to Xiaoyang Chen and Mattoo's (2004) analysis, MRAs with rules of origin hurt the exports of extra-regional developing countries (39 percent decline) more than they hurt extra-regional developed country exports (28 percent decline). In contrast, MRAs without rules of origin increase developing country exports to the region more than they increase developed country exports.

There has been little progress in the area of mutual recognition of conformity assessment procedures in the developing world. The APEC countries have initiated a major action plan to conclude wide MRAs among its members (by 2010 for industrialized members and 2020 for developing-country members) in regulated sectors (electrical and electronic equipment, medical devices, chemicals, etc.). The APEC countries signed an MRA in 1998 for telecommunications equipment that was predicted to increase intra-APEC trade in IT goods, which amounted to $\$ 45$ million that year (Maskus, Wilson and Otsuki 2001:26).

APEC, however, does not yet have a dispute resolution mechanism for differences in standards and conformity assessment. Nearly all the sub-regional free trade agreements in the Americas include provisions encouraging their members to consider mutual recognition agreements (exceptions being Canada-Chile and CARICOM-Dominican Republic agreements) (see Table 2). The Andean Community is developing an incipient MRA agreement between its members and Mercosur is considering doing it in the near future. 


\begin{tabular}{|c|c|c|c|c|c|c|c|c|c|c|c|}
\hline \multirow[b]{3}{*}{ Agreement } & \multirow[b]{3}{*}{ Services } & \multirow[b]{3}{*}{ SPS } & \multirow{2}{*}{\multicolumn{6}{|c|}{ Measures included }} & \multirow[b]{3}{*}{ MRAs } & \multicolumn{2}{|c|}{ Separate provision on } \\
\hline & & & & & & & & & & \multirow[b]{2}{*}{ Labeling } & \multirow{2}{*}{$\begin{array}{c}\begin{array}{c}\text { Protection } \\
\text { of } \\
\text { Environment }\end{array} \\
\end{array}$} \\
\hline & & & $\mathbf{s}$ & TR & $\mathrm{A}, \mathrm{T}, \mathrm{C}$ & CAP & AP & $\mathbf{M}$ & & & \\
\hline \multicolumn{12}{|l|}{ Customs Unions } \\
\hline EU & Yes & Yes & Yes & Yes & Yes & Yes & Yes & Yes & Yes & Yes & Yes \\
\hline MERCOSUR & Yes & Yes & Yes & Yes & No & Yes & No & Yes & Yes & No & No \\
\hline Andean Community & Yes & Yes & Yes & Yes & Yes & Yes & No & Yes & Yes & No & Yes \\
\hline $\mathrm{CACM}^{\mathrm{a}}$ & Yes & No & Yes & Yes & No & Yes & No & Yes & Yes & No & No \\
\hline CARICOM & Yes & No & Yes & Yes & No & Yes & No & Yes & Yes & No & No \\
\hline \multicolumn{12}{|l|}{ Free trade agreements } \\
\hline NAFTA & Yes & No & Yes & Yes & No & Yes & Yes & No & Yes & No & No \\
\hline Group of Three & Yes & No & Yes & Yes & No & Yes & Yes & Yes & Yes & Yes & No \\
\hline Bolivia-Mexico & Yes & No & Yes & Yes & No & Yes & Yes & Yes & Yes & Yes & No \\
\hline Chile-Mexico $^{a}$ & Yes & No & Yes & Yes & No & Yes & Yes & No & Yes & No & No \\
\hline Costa Rica-Mexico & Yes & No & Yes & Yes & No & Yes & Yes & Yes & Yes & Yes & No \\
\hline Mexico-Nicaragua & Yes & No & Yes & Yes & No & Yes & Yes & Yes & Yes & Yes & Yes \\
\hline Mexico-Northern Triangle & Yes & No & Yes & Yes & No & Yes & Yes & Yes & Yes & Yes & No \\
\hline Canada-Chile & No & No & No & No & No & No & No & No & No & No & No \\
\hline Central America-Chile & Yes & No & Yes & Yes & No & Yes & Yes & Yes & Yes & No & No \\
\hline Central America-Dominican Rep. & Yes & No & Yes & Yes & No & Yes & No & Yes & Yes & Yes & Yes \\
\hline CARICOM-Dominican Rep. & Yes & No & Yes & Yes & No & Yes & No & Yes & No & Yes & Yes \\
\hline
\end{tabular}

\section{RTA APPROACHES TO UPGRADING AND HARMONISING STANDARDS AND CONFORMITY ASSESSMENT.}

This section examines the potential positive and negative aspects of the RTA approach, the different types of RTA approaches, the general features of an RTA approach and its main challenges.

\subsection{POTENTIAL POSITIVE EFFECTS OF RTA UPGRADING AND HARMONIZATION}

A regional approach to upgrading and harmonizing standards and conformity assessment within the context of an RTA can provide stepping stones to greater participation in the global market. An RTA approach could help overcome the following gaps:

- Economies of scale: The upgrade and harmonization of standards and of conformity assessment at the regional level reduces trade barriers allowing member countries to fragment their production, become more competitive, and reach higher economies of scale in production. Xiaoyang-Chen and Mattoo (2004) analyze the impact of regional standards harmonization in developed RTAs (EC, EFTA, NAFTA, and $\mathrm{CER}^{8}$ ) and find that it can have a significant positive impact on trade within the region and with third countries. They find that implementing a

\footnotetext{
${ }^{8}$ CER is the Closer Economic Relations agreement between Australia and New Zealand.
} 
harmonizing directive in a manufacturing industry between two countries raises their imports from each other by 32 percent and imports from a third country outside the harmonizing region by ten percent. The first magnitude is explained by the reaping of greater economies of scale within the region and the second magnitude is explained by the reduction in the cost exporters in the third country need to incur to satisfy the standards of the members in the region.

RTAs can also help member countries realize economies of scale in the regulation of standards through the creation of regional bodies for regulation, accreditation, certification, metrology, inquiry points, and international representation. These regional bodies pool member countries' staff, finance, equipment, and infrastructure providing therefore a more cost-efficient service.

- Learning by doing: the interaction with other member countries during a process of deep regional integration can help a country better learn the complexities of the regulatory process and develop its regulatory capacity.

- Information failure: RTAs can help overcome informational gaps at three different levels:

0 Improve the management of information so that local firms are better informed about foreign standards. A regional body can gather information on foreign standards and share it with all firms in the region, rather than each member having to spend resources obtaining the same information. Greater knowledge about the standard requirements in different foreign markets would enhance transparency and predictability and would lead to a more effective and less costly management of information concerning standards at home and abroad.

o Participate more effectively in the shaping of international standards. Pooled financial and human resources would enable member countries to participate more effectively in the SPS and TBT committees and in international voluntary standards committees like ISO and IEC. Regional bodies can help develop common positions for international discussions of international standards.

o Provide a positive signaling effect (improve an image problem). If countries join up in an RTA with a member country that has internationally accredited laboratories or certification bodies (Product, Management System, Personnel), having their laboratories and certification bodies accredited by that country is likely to yield international accreditation.

- Division of labor: The mutual recognition of member countries' accreditation and certification services would grant firms access to the services of the certification and accreditation bodies of other member countries. This could eventually lead to the specialization of certification and accreditation bodies in the region in different products according to their expertise, allowing a more efficient use of resources and greater international recognition. 
- Trust: A process of regional integration leads to an environment where the different actors are more willing to negotiate the reform of standards and conformity assessment procedures. This is explained by the greater trust between members resulting from closer interactions, greater transparency, peer pressure and possible cross-issue retaliation.

- Greater effectiveness: Regional approaches to prevent or eradicate animal and plant diseases become simpler and more effective if SPS standards are harmonized across members.

\subsection{POTENTIAL NEGATIVE EFFECTS OF RTA UPGRADING AND HARMONIZATION}

An RTA upgrading and harmonizing could also have negative effects for some or even all of its members. Xiaoyang-Chen and Mattoo (2004) find that in those member countries with less stricter initial standards than the harmonized standard the benefits from harmonization in terms of intra-regional economies of scale can be offset by an increased production cost due to a stricter standard. However, this increase in production costs can be accompanied by greater extra-regional market access, since the member country is more likely to satisfy extra-regional standards requirements now that its products satisfy a stricter standard. The sign of the overall effect depends on the strictness of the initial standards, the strictness of the harmonized standard relative to that of extra-regional partners and the size of the country's intra-regional market relative to its extra-regional market.

If a country's exports to the region are small relative to its exports to the rest of the world, the adjustment costs of harmonizing at the regional level may outweigh the gains in intra-regional trade. The situation is worsened if the regional standards drive the country's standards away from those of its extra-regional partners, as it will cause a loss in extra-regional market access. In such a case, the country might be better off upgrading its standards unilaterally.

The returns to RTA harmonization can be reduced if regional bodies do not make good use of resources or there is low progress in standards and conformity assessment harmonization or if standards are set with protectionist intentions.

Lastly, a process of regional harmonization that sets stricter standards could divert trade away from low-cost extra-regional partners towards higher cost regional producers (Xiaoyang-Chen and Mattoo 2004).

\subsection{TYPES OF RTA APPROACHES TO STANDARDS UPGRADING AND HARMONIZATION}

This section focuses on two particular RTA approaches to standards upgrading and harmonization in the developing world, it draws some lessons from the EU experience and then examines the state of harmonization of conformity assessment procedures in these RTAs. 


\subsubsection{THE ONE GO APPROACH AND THE GRADUAL APPROACH}

Two main types of RTA approaches to standards upgrading and harmonization can be identified based on the speed at which standards are upgraded to the international standard: the one go approach and the gradual approach.

In the one go approach member countries upgrade their standards for the selected product in one go, setting it equal to the international standard. This approach was adopted for instance by the ASEAN countries. These countries have set a regional ASEAN standard equal to the international standard for 20 selected products - mostly from the electronics sector, a sector with low government regulation. Even if a member country does not adopt the ASEAN standard, it is obliged to accept the entry of products from a member country if they satisfy the ASEAN standards. ${ }^{9}$ If a country violates an ASEAN regulation, it can end up losing concessions or paying compensation. Such enforcement guarantees a positive return - in terms of market access - to a country's upgrading of its standards to the international level and thus promotes members' harmonization of standards at the international level. Another positive aspect of these agreements is that there is no need for standards committees to develop regional standards, since they are simply equated to the international standard.

The gradual approach is that followed by RTAs that do not wish to equate their standards to international standards for a particular product or for all products because their members' technological level or health, security and environment objectives are not aligned with international standards. This is the case for instance of the Andean Community and Mercosur. The criteria followed by the Andean Community and Mercosur to set regional technical regulations is the following. The regional technical regulation is based on the international standards, unless these are not compatible with the health, safety or environmental objectives of the region or its technological structure. That being the case, the regional technical regulation will be based on subregional, regional or national voluntary standards, in that order of preference. The regional voluntary standards in both RTAs are set trying to bring members' voluntary standards closer to international standards. ${ }^{10}$

The regional voluntary standards are set by members' standardization bodies (which are established by the private sector) and the regional technical regulations are set by members' technical regulation bodies (which are government bodies). By 2004, Mercosur had developed around 370 regional voluntary standards and 407 regional technical regulations (TBT and SPS). The Andean Community had harmonized technical regulations for 31 agricultural products, which represents around 60 percent of intraregional trade.

\footnotetext{
${ }^{9}$ The harmonization requirement is not applicable if a member country notifies that it is unable to adopt the international standard due to climatic conditions or infrastructure-related reasons.

${ }^{10}$ Section 4 explains in more detail how these regional standards are set.
} 
The one go and the gradual approaches are distinct from the approaches followed by other RTAs like NAFTA, FTAA, and the Group of Three (see Table 1), where members aim to make their standards compatible with each other rather than harmonize them.

\subsubsection{THE EU EXPERIENCE, WHAT HAVE WE LEARNT?}

The EU has the most comprehensive approach to harmonization of standards and conformity assessment. Its approach is markedly different from that of any other RTA and has undergone different phases.

Though by 1968 the EU customs union was complete, progress on the single market was blocked during a decade and a half by all manner of non-tariff barriers:

Up to 70 forms were needed by truck drivers crossing EC borders; public contracts were reserved for national companies; product standards and professional qualifications were neither harmonised nor given mutual recognition; service industries were largely confined to their own member state; capital movements were not liberalized (Leach 2000). ${ }^{11}$

The EU had been attempting before 1985 to set regional standards on the basis of members' unanimous decisions and specifying in great detail products' specifications. The EU realized that these features slowed down the elimination of non-tariff barriers and developed in 1985 the New Approach. ${ }^{12}$ This new approach is based on the principle of mutual recognition of standards or principle of equivalence: a country must accept the standards of member countries if such standards have the same objectives (they are then considered as equivalent). The burden of proof is not on the exporting firm but on the importer, who must prove scientifically that the objectives of the standards of the imported product differ from the objectives of the domestic product's standard. Only in those sectors where the principle of equivalence cannot be applied because of the great divergence between standards (like health and safety requirements), does the EU follow a process of harmonization of standards. Since 1986, decisions are not based on unanimity but on qualified majority voting.

Support for the new approach was strengthened by studies like that of Cecchini, Catinat and Jacquemin (1988) also known as the "Cost of Non-Europe Report" which estimated the costs of barriers like divergent standards and technical regulations, border controls and customs red tape, conflicting business law and protectionist procurement practice to cost $\$ 243,000$ billion.

The criteria used in setting EU technical regulations is based on the minimum requirement approach, which does not seek necessarily harmonization with international standards - unlike the Andean Community, Mercosur and ASEAN which do. Under this approach EU technical regulations are only concerned with guaranteeing health and security and protecting the environment and thus set only those specifications necessary

${ }^{11}$ Quote taken from Single market definition at http://www.euro-know.org/dictionary/s.html

${ }^{12}$ See European Commission (2000) for a detailed description of this approach. 
to guarantee these objectives. The rest of the product and process specifications are left to the private sector to determine through the setting of voluntary standards. These voluntary standards however must comply with the technical regulations. Technical regulations and voluntary standards are therefore complementary in the EU framework: the satisfaction of the voluntary standard implies the satisfaction of the technical regulation. This framework yields a very flexible system of voluntary standards and technical regulations that is quick in keeping up with technological changes. Technical regulations will not be as sensitive to technological changes as voluntary standards since they are only concerned with health, security and environment aspects, and not with the technical characteristics of the production process and the product, which are more prone to technological change. For example, technological advances in electronics affect the requirements of cars' motherboards - which would be regulated by voluntary standards but they are not as likely to affect a car's road safety features (which would be regulated by technical regulations). This leads to quicker adaptation to change since voluntary standards being set by the private sector are developed faster than technical regulations, which are set by public entities.

The EU harmonization process is also markedly different from that of Mercosur and the Andean Community in that the objective of the harmonization of SPS standards is the elimination of intra-community borders:

the advanced level of veterinary and phytosanitary harmonization has led to the abolition of intra-community borders since 1993 and free circulation of agricultural products (EU 1998:4.6).

In contrast, Mercosur and the Andean Community allow countries to keep their sanitary and phytosanitary independence. The harmonization of SPS standards does not have as an objective the elimination of intra-community borders since it respects the particular sanitary requirements of each member. Furthermore, compliance with a veterinary and phytosanitary standard in Mercosur does not prevent the application of the national importing process, including physical inspection.

The justification given in Report 4.6 .2 by Mercosur for not fully harmonizing SPS standards is that

as a result of the elimination of frontier controls inside the EC, the overall requirements for imports imposed by the EC tend to be higher than necessary as they may relate to the more extreme sub-regional situations (e.g. the Newcastle disease) (EU 1998:4.6).

However, no economic study has been performed to assess if the costs of having stricter SPS standards than are really necessary are greater than the benefits resulting from the reduction in trade barriers. The result of such analysis is likely to depend, among other factors, on the heterogeneity of sanitary conditions across member countries.

There are other significant differences between the EU and the Andean Community and Mercosur, which are presented in Table 3 and discussed in section 3.4. 
The EU approach is not without defects. The single market remains an uncompleted process:

financial services and public procurement are still far from being liberalized, compliance levels vary considerably between member states and anti-competitive practices abound" (Leach 2000) ${ }^{\mathbf{1 3}}$.

Leach (2000) argues that a vigorous program of mutual recognition of standards might have been at least as successful in promoting economic activity as the harmonization policies followed. ${ }^{14}$ Pelkmans, Vos and Di Mauro (2000) worry about the numerous Euopean standards created in some sectors and wonder if they have been subjected to a cost-benefit test to assess if they are contributing to economic optimality. They also point out that, in spite of the considerable efforts since the mid-1980s towards liberalizing, approximating standards, and applying mutual recognition; mutual recognition is still facing considerable practical problems and there is a worrying trend toward ever increasing national product regulation. This concern is shared by Pelkmans (2002) who criticizes the modest contribution of the principle of mutual recognition to the realization of free movement in the single market. He argues that business in the EU have been somewhat disenchanted by the many costs and uncertainty in its application in practice. $^{15}$ Businesses find it difficult and uncertain to verify the "equivalence" of objectives of health and safety between members. ${ }^{16}$ This is further aggravated by the absence of sectoral rule books and the next-to-prohibitive costs of monitoring the application of the principle. Pelkmans concludes that the solution consists of greater mutual recognition:

the manifold benefits of mutual recognition for Europe are too great to allow the present ambiguities to continue. The Union needs much more pro-active approaches to reduce the costs of mutual recognition as well as permanent monitoring structures for its application to services (analogous to those already successfully functioning in goods markets). Above all, what is required is a "mutual recognition culture" so that the EU can better enjoy the fruits of its own regulatory ingenuity (2002:2).

This mutual recognition culture among national authorities would stimulate permanent exposure to healthy competition throughout the EU market, without sacrificing justified health, safety and consumer protection concerns (Pelkmans 2002). This does not imply forgetting about harmonization. As Pelkmans notes, total liberalization, harmonization and mutual recognition all have limitations and no single method can suffice for all cases.

\footnotetext{
${ }^{13}$ Quote taken from Single market definition at http://www.euro-know.org/dictionary/s.html

${ }^{14} \mathrm{http} / /$ www.euro-know.org/dictionary/s.html

${ }^{15}$ Pelkmans notes that "[d]uring the mid-nineties the disenchantment with MR [Mutual Recognition] was so strong that that UNICE (the European confederation of industry) recommended a return to harmonization as a superior option” (2002:3)

${ }^{16}$ An analysis of the difficulties of determining and proving equivalence under the principle of mutual recognition can be found in Gardeñes-Santiago (1999).
} 
Table 3. Comparison of EU, Mercosur, and Andean Community strategies of harmonization of standards and conformity assessment

\begin{tabular}{|c|c|c|c|}
\hline & EU & MERCOSUR & Andean Community \\
\hline Type of agreement & Common market. & Customs Union. & Customs Union. \\
\hline $\begin{array}{l}\text { Institutional } \\
\text { configuration }\end{array}$ & Supranational. & Inter-governmental. & Supranational. \\
\hline $\begin{array}{l}\text { Technical reg. } \\
\text { standardization } \\
\text { body }\end{array}$ & ENTERPRISE Directorate-General. & CMG (Common Market Group). & Secretariat. \\
\hline $\begin{array}{l}\text { Voluntary } \\
\text { standards } \\
\text { standardization } \\
\text { body }\end{array}$ & $\begin{array}{l}\text { CEN (general standards), CELENEC } \\
\text { (electrotechnical standards) \& ETSI } \\
\text { (telecommunications standards). }\end{array}$ & $\begin{array}{l}\text { MCS (Mercosur Committee of } \\
\text { Standardization). }\end{array}$ & Secretariat. \\
\hline $\begin{array}{l}\text { Criteria in setting } \\
\text { regional standards }\end{array}$ & $\begin{array}{l}\text { Regional standard tends towards the } \\
\text { high range of members' initial } \\
\text { standards. }\end{array}$ & $\begin{array}{l}\text { International standards, then sub-regional } \\
\text { standards and then national standards. }\end{array}$ & $\begin{array}{l}\text { International standards first, then } \\
\text { national standards. }\end{array}$ \\
\hline $\begin{array}{l}\text { Harmonization } \\
\text { strategy }\end{array}$ & $\begin{array}{l}\text { Harmonization of tech. reg. led by } \\
\text { countries' demand and voluntary } \\
\text { standards by private sector. }\end{array}$ & $\begin{array}{l}\text { Harmonization of tech. reg. led by } \\
\text { countries' demand and voluntary } \\
\text { standards by private sector. }\end{array}$ & $\begin{array}{l}\text { Targeted harmonization. Led by } \\
\text { private sector and governments but } \\
\text { at times also by Secretariat with } \\
\text { strategic purposes. }\end{array}$ \\
\hline $\begin{array}{l}\text { Harmonization of } \\
\text { national tech. reg.? }\end{array}$ & $\begin{array}{l}\text { No, only required to satisfy minimum } \\
\text { requirements. Harmonization only in } \\
\text { special cases. }\end{array}$ & Yes. & Yes. \\
\hline $\begin{array}{l}\text { Voting structure to } \\
\text { set regional tech. } \\
\text { reg. }\end{array}$ & $\begin{array}{l}\text { Votes decided based on relative } \\
\text { majority. Votes weighted to account } \\
\text { for countries' economic size. }\end{array}$ & $\begin{array}{l}\text { Votes decided by unanimity. One member, } \\
\text { one vote. Unanimity slows down } \\
\text { decisions. Reform constrained by } \\
\text { heterogeneity in size. }\end{array}$ & $\begin{array}{l}\text { Votes decided by unanimity. One } \\
\text { member, one vote. Unanimity slows } \\
\text { down decisions. }\end{array}$ \\
\hline $\begin{array}{l}\text { Relationship } \\
\text { between tech. reg. } \\
\text { and vol. standards }\end{array}$ & $\begin{array}{l}\text { Complementary: tech. reg. sets } \\
\text { minimum requirements and vol. } \\
\text { standard specifies details. }\end{array}$ & $\begin{array}{l}\text { Competitive: tech. reg. are more } \\
\text { ambitious. No clear delimitation between } \\
\text { coverage of tech. reg. and vol. standard. }\end{array}$ & $\begin{array}{l}\text { Competitive: tech. reg. are more } \\
\text { ambitious. No clear delimitation } \\
\text { between coverage of tech. reg. and } \\
\text { vol. standard. }\end{array}$ \\
\hline $\begin{array}{l}\text { Involvement of } \\
\text { private sector and } \\
\text { consumers }\end{array}$ & High. & $\begin{array}{l}\text { Low (weak consumer groups, foreign firms } \\
\text { have large weight in private sector } \\
\text { participation in standards). }\end{array}$ & $\begin{array}{l}\text { Low (weak consumer groups, foreign } \\
\text { firms have large weight in private } \\
\text { sector participation in standards). }\end{array}$ \\
\hline $\begin{array}{l}\text { Perceptions of } \\
\text { standards by } \\
\text { private sector and } \\
\text { consumers }\end{array}$ & $\begin{array}{l}\text { Consumers perceive tech. reg. as } \\
\text { protecting their health. Private sector } \\
\text { perceives vol. standards as } \\
\text { necessary investment for } \\
\text { competitiveness. }\end{array}$ & $\begin{array}{l}\text { Consumers and private sector do not } \\
\text { realize importance of standards. }\end{array}$ & $\begin{array}{l}\text { Consumers and private sector do not } \\
\text { realize importance of standards. }\end{array}$ \\
\hline Implementation & $\begin{array}{l}\text { Compulsory once regulation } \\
\text { approved. }\end{array}$ & $\begin{array}{l}\text { Only compulsory if all countries adopt } \\
\text { resolution. No supranational power to } \\
\text { force countries to adopt resolution. }\end{array}$ & $\begin{array}{l}\text { Compulsory once regulation } \\
\text { approved. }\end{array}$ \\
\hline $\begin{array}{l}\text { Dispute settlement } \\
\text { institution }\end{array}$ & Fully operational. & Recently created. & Operational. \\
\hline $\begin{array}{l}\text { Financing of } \\
\text { national } \\
\text { standardization } \\
\text { bodies when they } \\
\text { assist in setting } \\
\text { regional standards }\end{array}$ & $\begin{array}{l}\text { Yes. EU gives money to national } \\
\text { standardization bodies. }\end{array}$ & $\begin{array}{l}\text { No. CMG and MCS ask national bodies to } \\
\text { develop standards to help in the } \\
\text { harmonization of non-regulated sectors } \\
\text { but do not pay them due to lack of } \\
\text { resources. }\end{array}$ & $\begin{array}{l}\text { Harmonization of standards is } \\
\text { financed by Secretariat. }\end{array}$ \\
\hline $\begin{array}{l}\text { Common positions } \\
\text { in international } \\
\text { standard bodies }\end{array}$ & $\begin{array}{l}\text { Standard bodies establish common } \\
\text { positions in international } \\
\text { organizations (ISO, ISE, CODEX, } \\
\text { WTO TBT \& SPS). }\end{array}$ & $\begin{array}{l}\text { No common position yet, except in } \\
\text { punctual cases. }\end{array}$ & $\begin{array}{l}\text { Secretariat is working to establish } \\
\text { common positions in international } \\
\text { organizations. }\end{array}$ \\
\hline $\begin{array}{l}\text { Regional } \\
\text { information point }\end{array}$ & Yes. & $\begin{array}{l}\text { Not yet developed. Greater efforts in } \\
\text { voluntary standards (by private sector). }\end{array}$ & Yes. \\
\hline $\begin{array}{l}\text { Conformity } \\
\text { assessment } \\
\text { procedures }\end{array}$ & $\begin{array}{l}\text { They have been aligned across } \\
\text { countries and a principle of } \\
\text { equivalence and mutual recognition } \\
\text { is in effect. }\end{array}$ & $\begin{array}{l}\text { There is a move to harmonize them. } \\
\text { Mutual recognition will be pursued in the } \\
\text { near future. }\end{array}$ & $\begin{array}{l}\text { Incipient mutual recognition of } \\
\text { conformity assessment procedures. }\end{array}$ \\
\hline $\begin{array}{l}\text { Conformity } \\
\text { assessment test }\end{array}$ & $\begin{array}{l}\text { At origin. Sporadic random post- } \\
\text { market tests in the market of } \\
\text { destination. }\end{array}$ & $\begin{array}{l}\text { Double testing (at origin and at destination } \\
\text { causing delays). }\end{array}$ & $\begin{array}{l}\text { At origin. Sporadic post-market } \\
\text { random tests in the market of } \\
\text { destination. }\end{array}$ \\
\hline
\end{tabular}




\subsection{GENERAL FEATURES OF AN RTA STANDARD AND CONFORMITY ASSESSMENT UPGRADING AND HARMONIZATION PROCESS.}

This section presents the general features of a regional upgrading and harmonization process of standards and conformity assessment procedures. These features are derived from the recent experience of the most advanced RTAs in terms of the speed of their standard upgrading and harmonizing - EU, Mercosur, Andean Community, and ASEAN.

\section{The harmonization of standards translates into greater market access and allows for greater interoperability (see Box 3).}

Box 3: Harmonization of standards leads to greater trade: examples in Mercosur and the Andean Community.

Mercosur: Dairy intra-regional exports grew at an annual growth rate of $13.9 \%$ from 1990 to 2000 (COMTRADE data). This growth is partially explained by the reductions resulting from the harmonization of technical regulations. The harmonization of voluntary standards in the automotive industry increased the interoperability of automotive parts and increased intra-regional trade in cars and trucks. With regard to SPS standards, the harmonization of cosmetic standards and of food colorants led to lower barriers and greater intra-regional trade in these products.

Andean Community: The decision 491 harmonized technical regulations for the weight of trucks. This was translated into a fall in the number of products blocked at customs. The harmonization of a voluntary standard on white sugar increased trade in white sugar, as it eliminated the blocking of imports on the basis of different sugar definitions.

Mercosur and the Andean Community have also harmonized their member countries' system of control and reporting of diseases and have harmonized their vaccination programs, limiting the impact of health shocks on trade.

The selected approach to harmonization is strongly influenced by the regulatory culture of the member countries and the strength of their institutions. Countries in Mercosur and in the Andean Community have governments with a strong regulatory culture and paternalistic attitude. In Mercosur and the Andean Community national (regional) technical regulations compete with national (regional) voluntary standards by setting detailed product and process specifications, unlike in the EU. As a result, changes in technology make it necessary to change both technical regulations and voluntary standards, which leads to a less dynamic standard system than in the EU - where in most cases it is only voluntary standards that need to be changed.

RTAs follow different criteria of standard harmonization. The new EU approach considers members' technical regulations as equivalent so long as a minimum set of criteria are satisfied. Only where the principle of equivalence is not possible due to the complexity of the product's regulation, the EU applies standards harmonization. Mercosur and the Andean Community apply a more ambitious harmonization process. They develop regional technical regulations and regional voluntary standards with the expectation that members will replace them for their old technical regulations and voluntary standards, respectively. As has already been mentioned, ASEAN countries set their regional standard equal to the international standard. 
RTAs generate climate of trust and closer relations between institutions. The close relationship between the different institutions within an RTA allows obstacles to be solved at times in informal ways before they are solved more formally. For instance, in the case of Mercosur, there is no mutual recognition of conformity assessment yet in paper, but many conflicts are de facto solved with a quick phone call to the respective person in the other member country. Furthermore, participants at standards negotiations in Mercosur noted that the climate in the negotiations notably improved as the regional integration process strengthened. ${ }^{17}$

The speed at which standards agreements are implemented depends on the power granted to the regional institution. The EU, the Andean Community, and ASEAN have supranational power and their member countries are obliged to incorporate the technical regulations into their national regulations. ${ }^{18}$ However, this is not the case in Mercosur. A Mercosur regional technical regulation is valid only when all member countries adopt it and incorporate it into their legislations. Since the institutional structure of Mercosur is intergovernmental and not supranational, there is no organism with enough authority to force a country to adopt a regional technical regulation. Around half the Mercosur technical regulations are not yet adopted. Lack of supranational power is translated into a lower degree of enforcement and lower speed of harmonization. In RTAs based on intergovernmentality, like Mercosur, the speed with which a member country adopts a technical regulation is influenced by the power vested to its national committee for technical regulations. In some Mercosur countries the SGT3 and SGT11 representatives have a level much below that of the minister and consequently the communication with the minister, who is the person who decides if the regional technical regulation will be incorporated in the country, is not as fluid as in other countries. There have been cases were the SGT representatives have agreed to a technical regulation for it to be later dropped by the minister. In the case of voluntary standards, none of the above RTAs imposes member countries to incorporate the regional voluntary standard, since its adoption is voluntary.

The voting structure affects the speed of integration. The EU in its initial stages of standard harmonization used the one-country one-vote unanimity system still used by Mercosur and the Andean Community for technical regulations. As previously reported, to increase the pace of harmonization the EU changed to a voting system where country's votes are weighted and decisions are made based on a qualified majority. Though there exists awareness in Mercosur that the one country one vote unanimity system leads to a slower progress, the disproportionate size of Brazil hampers changing the voting structure to one of absolute majority. In the case of regional voluntary standards, Mercosur takes the decision by consensus and the Andean Community by majority ( 3 out of 5), though the latter is considering switching to consensus in the near future.

\footnotetext{
${ }^{17}$ Based on interviews.

${ }^{18}$ In the case of ASEAN, a member country is obliged to accept imports that satisfy these standards even if it chooses not to incorporate the standards.
} 
There is no unique path to the harmonization of standards and the mutual recognition of conformity assessment procedures. The Andean Community, aware that its infrastructure condition and private sector awareness were worse than the EU's initial conditions, decided towards the end of the 1990s to change its approach. Its new approach to regional harmonization of standards and to mutual recognition of conformity assessment procedures is based on the following principles: ${ }^{19}$

- The creation of standards need not always be demand driven. Due to the low involvement of its domestic private sector in the creation of standards, the Andean Community is now following a supply driven approach. It is concentrating its standardization efforts in those sectors with large intra-industry trade rather than waiting for the private sector to demand such standardization. ${ }^{20}$ The hope is that the creation of standards in these sectors will awaken the private sector's demand for the setting of standards in other sectors.

- Mutual recognition of conformity assessment procedures need not take place after harmonization of standards. The Andean Community is following a different approach to that of other RTAs. Rather than placing all its efforts in harmonizing standards in a context where there is little involvement of the private sector, they are simultaneously harmonizing conformity assessment procedures and establishing mutual recognition of conformity assessments. ${ }^{21}$ This is possible thanks to the supranational authority of the Secretariat of the Andean Community. ${ }^{22}$ It has imposed mutual recognition for conformity certificates emitted by accredited institutions in those sectors where intra-regional trade is greater, though it does not cover SPS standards. The decision has already taken (Decisión 506), but its application is yet low. It is hoped that the creation of mutual recognition agreements will increase the private sector's demand for conformity assessment services and allow greater economies of scale in certification services (since borders are eliminated). This will motivate laboratories to upgrade, reducing differences across members and facilitating harmonization. These measures are complemented with technical assistance for accreditation bodies, which is being provided with EU collaboration. The objective is to ensure that the accrediting institutions are technically competent to accredit certification bodies, thereby facilitating mutual recognition at the Andean Community level and internationally.

- Strategic harmonization of conformity assessment procedures. Once members' conformity assessment procedures in those sectors with greater intra-regional trade are brought closer, the Andean Community plans to harmonize the conformity

\footnotetext{
${ }^{19}$ Based on interview.

${ }^{20}$ See Resolución 313 Actualización del Reglamento de la Red Andina de Normalización, $8^{\text {th }}$ of November 1999, General Secretariat of the Andean Community.

${ }^{21}$ See Decisión 506 Reconocimiento y aceptación de certificados de productos que se comercialicen en la Comunidad Andina, $22^{\text {nd }}$ of June 2001, Commission of the Andean Community.

${ }^{22}$ In those countries where there is no accredited laboratory, the Andean Community provides a provisional accreditation "Organismo de certificación reconocido" to a laboratory and the certificates that it provides to products have to be recognized by other members (see Decision 506 of 2001 of the Andean Community).
} 
assessment procedures of other products in the same production chains to ensure better interoperability.

- The Andean Community Secretariat has set best practice guidelines in technical regulations. Such guidelines guarantee that the creation of new technical regulations in member countries will be easier to harmonize regionally. ${ }^{23}$ The creation also of a regional notification system that uses the same format as WTO lowers members' cost of notification to the regional body and the WTO. ${ }^{24}$

The main focus of standard harmonization in Mercosur and the Andean Community is to reduce barriers to intra-regional trade. However, they also focus on extra-regional trade to the extent that they set as their first criteria for regional standards getting closer to international standards (see Table 2).

The type of products considered for harmonization of voluntary standards tends to differ from those considered for harmonization of technical regulations. The private sector, which is mainly responsible for setting regional voluntary standards, tends to harmonize first those sectors that are not heavily regulated by technical regulations, which are set by governments. The reason for this is that harmonization of voluntary standards in sectors heavily regulated by unharmonized technical regulations would be more difficult. For instance, Mercosur's initial efforts setting regional voluntary standards dealt mainly with the steel, iron and non-metal sector, whereas the regional technical regulations dealt mainly with the automotive and food sectors.

The speed of harmonization between standards towards a regional standard tends to be greater in the case of manufactures than primary goods for two reasons. The first is that agricultural products tend to be traditional sectors where national standards have been set time ago, whereas the human-capital-intensive manufacturing sector tends to be integrated by more recent industries where firms behave as standard-takers of foreign standards (Berlinski 2001). The second reason is that primary goods are more affected by sanitary and phytosanitary concerns than manufactures, which tends to slow down the harmonization process. This is the case for instance in Mercosur, which has seen limited harmonization in primary products like meat, seeds and food content.

The speed of standards harmonization is influenced by the similarity in export composition between members. In South-South RTAs like Mercosur and the Andean Community where members' have similar production composition the private sector tends to be reticent to harmonize the standards of sensitive sectors for fear of their markets being flooded by imports from member countries. In North-North agreements like the EU - where members also have similar production composition - the problem is smaller since the weight of manufactured products in members' production is larger and

\footnotetext{
${ }^{23}$ See Decisión 562 Directrices para la elaboración, adopción y aplicación de Reglamentos Técnicos en los países miembros de la Comunidad Andina y a nivel comunitario, 25-26 of June 2003, Commission of the Andean Community.

${ }^{24}$ This notification system is similar to that of the EU (TRIS), Canada (SCC) and USA (NIST). See http://www.comunidadandina.org/sirt .
} 
such products have more potential for intra-industry trade than primary goods. NorthSouth agreements are less likely to face this type of challenge so long as the North allows entry to its protected agricultural sector.

RTAs have allowed members to present a common position in international organizations and influence the setting of international standards. This has been particularly the case in the EU and there appears to be some movement in this direction in the Andean Community and Mercosur (see Box 4). The Secretariat of the Andean Community is working to establish common positions among its members and provides also assistance to its members in the setting of bilateral trade agreements with nonmember countries. The setting of common positions in international forums is still incipient in Mercosur.

Box 4: Cooperation between member countries to influence international organizations: the cases of Mercosur and the Andean Community.

The Mercosur countries spurred by the spread of SARS influenza recently presented a joint proposal at the OMS for a new plan of emergency contention of epidemics and took a leading role in its development. The Mercosur countries regularly participate in the IOE (International Office of Epizoots) through COSAVE and have taken common positions on phytosanitary issues.

The Andean Community is working on a joint Andean proposal for the assessment of phytosanitary levels of risk, which will be presented shortly to the IOE for its consideration in developing standards of phytosanitary risk.

Allowing non-members to have a voice in the process of regional harmonization of standards allows for the possibility of these countries joining the RTA in the future. This was the case with the EFTA countries and the EU and could be the case between Mercosur and its associate members Bolivia and Chile. ${ }^{25}$

\subsection{CHALLENGES FACED BY RTA STANDARD APPROACHES}

This section presents some of the main challenges faced by Mercosur, Andean Community, and ASEAN in the upgrading and harmonizing of their standards and conformity assessment procedures.

There is a wide discrepancy between what is signed in a regional standards agreement and what is later applied, particularly in RTAs integrated by developing countries like Mercosur. Though Mercosur seems to have made great progress on paper in standards cooperation and trade integration, the reality is bleaker. In spite of its apparent progress, a study by the European Central Bank places Mercosur at the same level of economic integration as the EU in the 1960-1970s (Dorrucci, Firpo, Fratzscher and Mongelli 2002). Institutional integration in Mercosur is also found to be modest by these authors. It transpired from the interviews performed by the author in Mercosur countries that while institutional weaknesses play a role in the great disparity between

${ }^{25}$ The main obstacles in the case of Chile are not so much differences in standards, but in tariffs. 
what is agreed and what is implemented, the main cause appears to be lack of political will by governments.

The disparity between members in their economic policies and institutional development limits the speed of harmonization of standards and conformity assessment procedures. The lack of harmonization of macroeconomic policies between members in the Andean Community and in Mercosur has led to governments going back on their promises on standards to protect their markets during crisis. Lack of transparency has allowed customs to reinterpret the meaning of the standard or to delay products with all type of pretexts for protectionist reasons. ${ }^{26}$ This has had a long-lasting effect on Mercosur's harmonization process as it has led to lasting distrust and uncertainty and to firms diverting exports away from conflictive products (Berlinski 2001). The extent of institutional disparities between members also affect the speed with which an agreement on mutual recognition of conformity assessment procedures can be reached, as such agreement requires first the upgrading of the accrediting, testing and certifying institutions in those member countries with weaker institutions. The challenge faced by Mercosur and the Andean Community is thus greater than that initially faced by the EU as the disparities between members are larger.

There is a lack of transparency in many developing countries in the setting of standards and conformity assessment procedures. Greater transparency increases the accountability of government officials and the chances that standards and conformity assessment procedures address the needs of the market and of consumers. It also reduces the level of uncertainty for firms, as it improves the transmission of information and lessens arbitrary changes in policy. Greater transparency is a challenge for members in Mercosur and the Andean Community, where governments are not accustomed to a high degree of transparency in the setting of regulation. Though the EU, the Andean Community, and Mercosur all publish their resolutions in the web, Mercosur is overall not as transparent as the Andean Community. With the exception of Brazil, the other Mercosur members do not publish the Mercosur resolutions in their official websites. Brazil publishes all of Mercosur's resolutions in its official bulleting and in its website before adopting them and conducts public audiences to which all society is invited to get its reactions to the resolutions. In order to improve the transmission of information to the private sector, the Andean Community has created email lists of different groups of firms to inform them when WTO or Andean Community members notify a proposed change in their standards, so that the firms can send their objections. The ASEAN community overrides the problem of lack of transparency by adopting the clearly stated international standards.

Many RTAs start the harmonization process without clear criteria as to what standards to prioritize. This was the case in Mercosur and the Andean Community, which started the process with broad and ambitious programs that had later to be refined as they were not effective and proved too costly. In the case of Mercosur, the initial harmonization approach tried to cover as many standards as possible and led to an

\footnotetext{
${ }^{26}$ There are claims that at times, when domestic production is threatened by a surge of imports, the destination country has delayed the registration of those imported products so as to delay their entry.
} 
excessive regulation of technical regulations and voluntary standards at the regional level. Harmonization in Mercosur and the Andean Community is now more prioritized focusing on those standards that create significant barriers to trade, and regional technical regulations are now developed with less detail. Cooperation between the Mercosur Association of voluntary standards (AMN) and the Mercosur Common Group responsible for TBT technical regulations (GMC) has also been increased to delimit more clearly the coverage of technical regulations and of voluntary standards and reduce overlapping. However, the present approach of the Andean Community and Mercosur is still far from the EU's minimalist approach.

Slow harmonization of standards results in outdated standards. Due to the dynamic nature of standards, it is essential that regional standards be quickly adopted by member countries and be modified accordingly when international standards change due to technological changes. Mercosur's regional food standards have not incorporated the most recent changes in CODEX and this has led to new national standards being used as trade barriers, as in the case of some member countries' labeling standards. The excessive use of ad hoc solutions to problems resulting from the slow adoption of regional standards and the lack of mutual recognition of conformity assessments can have a similar effect to sporadic restrictions, as they introduce uncertainty which reduces exports and increases the costs associated with the minimizing of such uncertainty (Berlinski 2001).

Consumers and the private sector in the developing world are not yet aware of the importance of standards. The levels of participation of consumer groups and the private sector in the setting of national and regional standards in developing countries are still very low. Unlike in the North, firms do not yet see a standard as an investment to remain competitive and absorb foreign technology, but as a protectionist instrument. Firms are therefore reticent to pay standardization agencies for the development of a new standard. For instance, honey firms in Uruguay were interested in setting a honey standard to prevent intermediaries from paying them a lower price with the excuse that the sugar content of the honey is too high or too low. However, they were not prepared to pay the Uruguayan standardization agency UNIT the cost of setting such a standard. Consequently, agencies like UNIT in Uruguay or IRAM in Argentina are forced to subsidize the setting of voluntary standards with their certification activities. The low participation of local firms in standards setting has two effects: first, a large percentage of firms that participate in the setting of standards in Mercosur and the Andean Community are foreign owned, and second, standards bodies have greater power in the standards setting process than in developed countries. Both features can lead to standards that do not truly reflect the interests of the region.

Small and medium enterprises generally are excluded from the setting of standards and cannot afford getting certification or metrology services. This is due to the relatively high representation cost at national committees on voluntary standards and the relatively high cost of certification and of metrology tests. This could translate into regional voluntary standards that do not reflect the interests of small and medium enterprises and into difficult market access for these type of enterprises, which cannot 
generally afford getting certified or get their metrology tested. SEBRAE, a Brazilian private institution that provides support services for micro and small enterprises, has developed a bold approach at the national level to overcome these problems. It also facilitates access to information on standards and promotes certification and metrology awareness across micro and small enterprises to create a larger demand for accreditation and certification services and increase the supply of such services across the country. SEBRAE also provides "solidarity certification", which consists of jointly certifying groups of small and micro enterprises to reduce certification costs. It also provides bonds that subsidize fifty percent of micro and small enterprises' expenditure in metrology services.

A process of harmonization of standards can be kidnapped by some pressure groups and used for protectionist reasons. This was the case for instance with the development of a regional wine standard in Mercosur (see Box 5). There is the danger that protectionist reasons could also shape a future Mercosur bottled water labeling standard. The large bottled water companies in some member countries report on the label of the bottles excessive information about the properties of the water (like electrical conductivity or temperature of the water at the fountain). If such information is introduced as a requirement in a regional voluntary standard, it could serve as a barrier to entry to small bottled water companies (as they cannot bear the costs of such tests) reducing competition, which could result in higher prices for consumers. There is also the danger that the process of harmonization be kidnapped by member countries' standards bureaus guided by a principle of institutional self-preservation rather than simplification and efficiency.

\section{Box 5: The setting of regional standards with protectionist intentions: the case of Mercosur's wine} standard.

The Mercosur countries agreed on setting a regional wine standard that forbids the import of wine in barrels. The argument given was that barrels do not preserve the quality of the wine as well as bottles. The real reason was the protection of the wine industries of some Mercosur members. The wine industry in Brazil and Uruguay had lobbied for the creation of such standard to prevent the large entry of better quality and cheaper Argentinean wine. It appears the agreement was reached due in part to the lack of negotiating experience of the Argentinean technical committee on wine (Nofal 2004).

Mutual recognition of conformity assessment procedures is necessary for harmonization of standards to effectively reduce barriers to trade. However, RTAs in the developing world are advancing more quickly with the harmonization of standards than with the harmonization of conformity assessment procedures. A possible reason for governments' less enthusiastic approach to harmonization of conformity assessment procedures is that it would impede the use of these procedures with protectionist intentions. With the exception of the EU, RTAs are still far form incorporating mutual recognition of conformity assessments. 


\section{A WAY FORWARD}

This section suggests principles that could guide developing countries in the regional upgrading and harmonizing of their standards and conformity assessment procedures. ${ }^{27}$

\subsection{SUGGESTED PRINCIPLES FOR THE UPGRADING AND HARMONIZATION OF}

\section{STANDARDS AND CONFORMITY ASSESSMENT}

There is yet no clear best practice in the upgrading and harmonizing of standards and conformity assessment procedures. However, it is possible to draw some common principles from RTAs' past experiences and existing literature that can serve as guide to countries pursuing regional upgrading and harmonization of standards and conformity assessment procedures. These principles are particularly relevant for RTAs integrated by developing countries with a low developmental stage and with low technological capacity that are seeking to gradually upgrade and harmonize standards at intermediate levels to get closer to international standards, rather than set them equal to international standards in one go.

1- Prioritize: A first step is to identify priority sectors for standards reform to keep costs low and gather momentum for reforms in other sectors. The sectors to prioritize are those where trade costs arising from differences in standards and conformity assessment procedures are higher and where trade between members is larger.

2- Build trust: Trust between member countries is an important determinant of the success of the harmonization of standards and of conformity assessment procedures. To build this trust, it is important to have a balanced approach to the reforms so that all members perceive that there are gains to be gained from the process by all members.

3- Need for a quality strategy: To keep the reforms focused, it is important that regional regulators show that that their proposed regulations will meet the required quality before they adopt them. Regulators could use as a reference the OECD Checklist for Regulatory Quality (Jacobs 2004).

Jacobs (2004) identifies five characteristics that are needed for a country to have a quality regulatory system. These characteristics can also be extended to a quality regional regulatory system:

1. Security: predictable enforcement of the rule of law and respect for market solutions.

2. Transparency: clear and simple rules, openness through the entire policy process, and less corruption.

3. Legitimacy: must protect consumer safety, health, and the environment.

\footnotetext{
${ }^{27}$ A longer version of this section, which includes suggestions for a more effective and rewarding participation of developing countries in the international standards arena, is available on request.
} 
4. Efficiency: low-cost rules, timely decisions, and swift movements to meet market needs.

5. Expertise: good regulatory skills and understanding of complex markets and technologies.

A quality national and regional regulatory system can be strengthened by programs promoting awareness among consumers, consumer defense groups and firms of the importance of standards to improve quality and safety, to reduce consumer search costs, and to increase firms' market access into higher value added markets.

In establishing regional regulations, it is also important to perform a Regulatory Impact Analysis to stimulate consultation with member countries and their societies and estimate the costs and benefits of such changes. The needs of consumers must be taken into account even if consumer groups are weak and lack representation in the negotiations. This will help prevent the creation of standards by the private sector with protectionist motivations. It is important to learn from past mistakes and successes of previous upgrading and harmonization processes of other RTAs (particularly the EU, which is the most advanced in this area) so as to leap frog obstacles rather than repeat the past mistakes of others. Mercosur is not yet doing so, as it is still following the old approach of the EU. There is little knowledge both in the Andean Community and in Mercosur of each other's experiences and of the EU's new approach. Countries' should also ensure that national technical committees dealing with standards and conformity assessment are not replaced with changes in government to avoid the loss of human capital acquired through learning by doing and through regional cooperation.

4- Simplification and dynamism: In the context of limited resources, a simplification of the regulation and of the number of standards is a better compromising policy than setting a complex system that overburdens the limited capacity of members and regional bodies. While poor and inadequate regulatory structures permit informality and corruption, these features are also associated with heavy regulation. Adapting institutions to new roles and functions that serve social and market needs is vital to public support for reform. A simpler regulation makes it easier for regional bodies to better represent the interests of its members both in designing regulations and in trade agreements with the region's trading partners. This simplification includes the streamlining of responsibilities of relevant monitoring, certification and enforcement agencies; as well as the elimination of overlapping of functions and responsibilities between the different state bodies comprising a country's national standards system. Since standards are dynamic by nature, it is important that the harmonization process be not only simplified but also made flexible and dynamic so that regional standards are suitably modified with changes in technology and level of development.

Developing countries could consider implementing the EU's principle of minimum essential requirements to simplify and speed up the process of standards upgrading. Harmonization would be limited to essential requirements, rather than pursuing complete harmonization of standards. There would be a clear distinction between 
technical regulations and voluntary standards: technical regulations should specify the product's minimum essential requirements and voluntary standards should specify the rest of the details in a consistent manner with the essential requirements. This distinction would simplify a region and member countries' regulatory system - since it leads to less overlapping of technical regulations and voluntary standards - and reduce information costs for producers - the satisfaction of voluntary standards guarantees the satisfaction of technical regulations. ${ }^{28}$ This distinction would also make the region and members' regulatory system more dynamic in adapting to technological changes.

5- Gradual reform: A gradual upgrade of regional standards and conformity assessment procedures will allow members in a low development stage to better adjust to the changes and assimilate their cost. Furthermore, when the setting of higher technical regulations might be slowed down by vested interests, an initial measure that can be followed is to make the changes to standards voluntary for a selected range of export products. This permits eager exporters to immediately adopt these new standards and achieve greater market access. This approach is followed in Mercosur: when the technical regulation body Common Market Group wants to develop a technical regulation in an unregulated product, it first asks the standardization agencies to create a voluntary standard. It later develops a regional technical regulation based on the voluntary standard.

6- Capacity building: Develop a training program for civil servants of member countries to capacitate them to implement the necessary standards reforms and strengthen the financing, infrastructure and human capital of regional bodies to guarantee their effective functioning. Mercosur for instance is constrained by its limited staff numbers and financial resources. Capacity building can be obtained as a component of bilateral trade agreements with partners like the EU (as is the case in EU's agreements with the Andean Community and Mercosur), from ISO's Five Year Action Plan to develop capacity in developing countries and increase national and regional cooperation, from the recent WTO fund for technical assistance on standards (Calzadilla-Sarmiento 2005) and from donors. Note however, that the actual services need not be only provided by Northern institutions, they can also be provided by institutions of developing countries - with financing from donor agencies. This last strategy is attractive because of the advantages of peer evaluation - institutions from developing countries are more aware of developing countries' particular context. Such capacitation is already taking place (for example UNIT and INMETRO have provided capacitation in many Latin American countries) but there is a need for financial aid to extend these services. ${ }^{29}$ Brazil submitted a proposal of this nature in 2001 at the WTO TBT committee, but there has yet been no progress in this area.

\footnotetext{
${ }^{28}$ Consequently, producers need not worry about finding out which are the technical regulations that address their product - as long as they satisfy the voluntary standards, they will be satisfying the technical regulations.

${ }^{29}$ These institutions provide these services with the long run objective of increasing conformity assessment capacity in neighboring countries, which would allow eventual mutual recognition and greater trade.
} 
7- Mutual recognition of conformity assessment procedures: An upgrading and harmonizing of standards will only be effectively translated into greater market access if a member country's conformity assessment procedures are recognized by other members. For mutual recognition to be achieved, member countries need to upgrade their certification, accreditation and enforcement capacity to similar levels. In addition, this process should include the strengthening of quality inspections at borders, ports, and production points, as well as improving regional and national infrastructure for transportation and for pack houses to improve delivery quality and reduce the number of products rejected for SPS reasons. One efficient way of achieving mutual recognition of conformity assessment procedures is to profit from economies of scale by setting up accredited regional service providers for testing, inspection and certification. These regional service providers could serve both domestic and exporting firms. This would eliminate the need for double testing and would limit the use of conformity assessment with protectionist intentions.

An alternative option would be for members' bodies to specialize in different standards - rather than the respective bodies in a country providing accreditation and certification services for all product standards - so as to achieve greater economies of scale. This is what the Andean Community intends in the case of certification services under its new approach to mutual recognition of conformity assessment (Decisión 506), but is not the case in Mercosur. It does not make sense for developing countries with a small domestic market like Uruguay to have recently created an accreditation body (OUA) and for its laboratories to have expertise in the certification of all products. At present Uruguayan laboratories are forced to get accredited by the OUA to be able to certify some products although they are already accredited by INMETRO from Brazil, an institution of greater accreditation recognition. This increases costs for laboratories in terms of greater accreditation fees and more frequent auditing (a process that generally takes two to three days time per audit).

Improving the quality of laboratories would also strengthen the capacity to conduct risk analysis and other scientific research. These analyses can provide critical evidence to boost negotiating capacity at WTO meetings and resolve disputes that may arise.

In the absence of an MRA of conformity assessment procedures with extra-regional partners, an interesting strategy could be to have inspectors from the extra-regional partner at the harbor of origin - this is the case with Japanese inspectors in Ecuador. This decreases costs since it is cheaper to have products non-compliant with the standards of the destination country rejected at origin rather than at arrival, particularly so in the case of perishable goods.

8- RTAs should also intensify their standards negotiations with other trading blocks and countries to achieve greater recognition of each other's standards and conformity assessments and gain greater market access. Countries should increase their disposition to recognize as equivalent other countries' standards and conformity 
assessment procedures when they fulfill the same objectives to lower transaction costs and increase trade. However, member countries should take into account their RTA standard commitments when setting bilateral agreements with non-RTA members to ensure that the agreements are compatible and the integration process is not derailed. At present, Andean Community members are individually setting bilateral trade agreements with the US without taking into account their prior regional commitments, making more difficult the Andean Community harmonization process. In contrast, the forthcoming negotiations with the EU are going to be made at the level of the Andean Community and this is likely to strengthen its integration efforts.

\section{CONCLUSION AND POLICY IMPLICATIONS}

This paper has provided a first step towards analyzing different regional approaches available to developing countries in upgrading their standards and conformity assessment procedures, and hopes to stimulate further research in the area. The main findings of the study are:

There are different paths available to upgrade standards. A country can upgrade its standards unilaterally or in a coordinated manner, be it a cooperation agreement approach or an RTA approach. These paths are not mutually exclusive. Countries have followed differing paths across time and across products. The suitability of the different paths for a developing country depends on the country's level of development, the institutional type of agreement and the product concerned.

Upgrading standards and conformity assessment procedures unilaterally to international levels is the simplest process. In products where international standards are commonly accepted and the country's production structure is sufficiently developed, upgrading unilaterally to international standards would be advisable as it leads to greater market access both intra-regionally and extra-regionally. However, this strategy might prove costly for products where satisfaction of international standards does not guarantee market access, since the costs of restructuring production to such high standards might outweigh the benefits. It might also not be a suitable strategy for those countries that do not wish to equate their standards to international standards for a particular product or products because their technological level or their health, security and environment objectives are not aligned with international standards. In both cases, a coordinated path is particularly appealing as it guarantees greater market access if a standard level is reached and it allows for the possibility of countries gradually upgrading towards international standards.

The particular coordinated path followed by a developing country depends on the institutional sophistication of the trade agreement. A cooperative agreement approach (such as that of APEC or of bilateral trade agreements) has less enforcement power than an RTA approach, and can therefore encounter greater obstacles if some members are not fully committed to the upgrading process. However, there are some sectors like the technological sector and some areas like metrology where there is stronger willingness to upgrade because of their high returns and smaller potential adverse effects - and thus the 
smaller need for enforcement. In these sectors and areas a cooperative agreement approach can be a promising venue for standards and conformity assessment upgrading. In sectors where there are clear winners and losers to harmonization, cooperation without strong enforcement can be more difficult to achieve. Low tariffs could diminish the potential problem of tariffs being used for protection once standards are harmonized under a cooperative agreement approach.

An RTA approach involves not only the upgrading of standards, but also the regional harmonization of standards. In the case of an RTA approach like ASEAN the harmonization is set at the level of the international standards. This saves resources since regional standards bodies are not needed. However, the cost of setting standards at the international level might be too costly for an RTA if the member countries' technological development and their health and safety objectives are very different to OECD countries, which are the countries that generally set the international standards. In such RTAs, harmonizing regionally at intermediate standards levels and gradually upgrading standards towards international standards, as Mercosur and the Andean Community are doing, might be a more suitable option.

A country can combine different paths for different products. If a developing country has higher standards than the other RTA member countries in a particular product and it has a sufficiently developed institutional framework, it can unilaterally raise its standard for that product to the international standard. So long as the country accepts entry of products satisfying the regional standard and so long as the satisfaction of the higher international standard allows for the satisfaction of the regional standard, the RTA approach is compatible with the unilateral approach. The country can therefore gain both greater intra-regional and extra-regional market access in that product. Similarly, the RTA approach can be compatible with a simultaneous cooperative agreement approach with other non-member countries so long as the country's standards undergo a gradual upgrading process towards the international standards consistent with the cooperative approach.

To date, RTAs in the developing world have not begun to realize their full potential for overcoming standards related obstacles to regional or global trade. Countries need to speed up and more effectively implement their upgrading and harmonization efforts to achieve greater returns in terms of market access and to better meet their health and environment objectives.

Developing countries have a much lower participation rate in international standard organizations (ISO, IEC, TBT and SPS) than developed countries members of RTAs. While developing countries

make up 73 percent of ISO membership, they still hold only 5 percent of the secretariat positions. Increasing their participation would allow developing countries to have a greater say in ensuring that international standards reflect their needs (Hufbauer, Kotschwar and Wilson 2001:8). 
The main reason for this low participation is the high cost of representation and the lack of coordination between RTA members.

\section{Bibliography:}

Andean Community (1999) Resolución 313 Actualización del Reglamento de la Red Andina de Normalización, $8^{\text {th }}$ of November, Secretariat of the Andean Community.

Andean Community (2001) Decisión 506 Reconocimiento y aceptación de certificados de productos que se comercialicen la Comunidad Andina, $22^{\text {nd }}$ of June, Commission of the Andean Community.

Andean Community (2003) Decisión 562 Directrices para la elaboración, adopción y aplicación de Reglamentos Técnicos en los países miembros de la Comunidad Andina y a nivel comunitario, 25-26 of June, Commission of the Andean Community.

Andison, Drew (1996) "Product Standards and their Impact on International Trade” Paper presented to the Australian APEC Study Centre's first annual conference on International Trade, Education and Research, http://www.apec.org.au/docs/citer10.htm, accessed the $14^{\text {th }}$ of April 2005.

Berlinski, Julio (2001) "Las Restricciones no arancelarias a exportaciones en el MERCOSUR: Un análisis comparativo", chapter 1, Sobre el beneficio de la integración plena en el MERCOSUR, Ed. Julio Berlinski, Siglo Veintuno de argentina Editores.

Brenton, P. (2004) "Standards, Conformity Assessment and Trade: Modernization for Market Access," Chapter 5, Moldovia Trade Integration Study, The World Bank, Washington DC.

Cecchini, Paolo, Michel Catinat, and Alexis Jacquemin (1988) The European Challenge, 1992, Wilswood House Limited, England, pp.1-127.

Commission of the European Communities (2001) "Statistical and Technical Annex to the 'Report on the functioning of Community Product and Capital Markets'”, Brussels, 7.12.2001 SEC (2001) 1993.

COMTRADE (2004) Data extracted using the WITS program.

Calzadilla-Sarmiento, Bernardo (2005) "International Standardization: Challenges for Developing countries," Seminar presentation at the World Bank, Washington DC, $20^{\text {th }}$ of April.

Dorrucci, E., S. Firpo, M. Fratzscher and F.P. Mongelli (2002) "European Integration: What Lessons for Other Regions? The Case of Latin America," European Central Bank, Working Paper Series No. 185, October.

EU (1998) "Joint Photography of Trade Relations between the European Community \& Mercosur", Chapter $\quad 4$ Trade standards and disciplines, http://europa.eu.int/comm/external_relations/mercosur/bacground_doc/report_photo 4.htm, accessed the 14th of April 2005.

European Commission (2000) "Guide to the implementation of directives based on the New Approach and the Global Approach,” Luxembourg: Office for Official Publications of the European Communities, http://europa.eu.int/comm/enterprise/newapproach/newapproach.htm, accessed $10^{\text {th }}$ of January 2005.

Financial Times (2004) "EU and Asean to pave way for trade pact talks" article dated the $9^{\text {th }}$ of September.

García Jiménez, G and M. Gardeñes Santiago (1997) "Technical standards in a context of regional integration agreements" in Regionalism and multilateralism after the Uruguay Round: convergence, divergence and interaction, ed. P. Demaret, J.-F. Bellis and G. García Jiménez. Brussels: European Interuniversity Press, p. 631-658.

Gardeñes-Santiago (1999) La Aplicación de la Regla de Reconocimiento Mutuo y su incidencia en el comercio de mercancías y servicios en el ámbito comunitario e internacional, Editorial Eurolex, Madrid, España, pp.1-430. 
Hufbauer, Gary Clyde, Kotschwar, Barbara and Wilson, John S. (2001) "Trade Policy, Standards, and Development in Central America" World Bank Policy Research Working Paper No. 2576. http://ssrn.com/abstract=632645

Jacobs, Scott (2004) “Regulation and Standards: Best Practice Principles Behind the Borders”, presentation given at "Trade Facilitation and Development: From Theory to World Bank Practice” a training course by the Transport and Urban Development Department and PREM International Trade Department, World Bank, Washington DC, March 31.

Jaffee S. and S. Henson (2004) "Standards and Agro-Food Exports from Developing Countries: Rebalancing the Debate,” World Bank Policy Research Working Paper No. 3348.

Kotschwar (2001) “Standards and Technical Barriers to Trade,” Chapter 7 in José M. Salazar and Maryse Robert, eds. Towards Free Trade in the Americas. The Brookings Institution.

Le Blanc, R. (2002). “Histoire de la Palette aux Etats-Unis (1890-1960) ”, Pallet Enterprise, May, available in a French version at www.europal.net/Fr/Infos/Actualite/Actu/art/emballage/histpalusa.shtm.

Leach, Rodney (2000) “A Concise Encyclopedia of the European Union: From Aachen to Zollverein” 3rd Edition, Profile Books, London, website edition: http://www.euroknow.org/dictionary/index.html

National Wooden Pallet and Container Association, www.nwpca.com, accessed June 2004.

Nofal, Beatriz (2004) Constructing a deeper integration in MERCOSUR. Background paper for the Global Economic Prospects 2005. Washington DC: World Bank.

Organization for Economic Cooperation and Development (1996) Proceedings from the Conference on Consumer Product Safety Standards and Conformity Assessment: Their Effect on International Trade. Paris.

Otsuki, Tsunehiro, John S. Wilson, and Mirvat Sewadeh (2001b). "Saving Two in a Billion: Quantifying the Trade Effect of European Food Safety Standards on African Exports." Food Policy 26:495514.

Penman, I. (1997). “Efficient Unit Loads”, Logistics Focus, June, pp.2-6.

Pelkmans, Jacques (2002) “Mutual Recognition in Goods and Services: An Economic Perspective”, BEEP briefing no.2, chapter for a book, edited by Fiorella Kostoris Padoa Schioppa, The Principle of Mutual Recognition in the European Integration Process, Rome.

Pelkmans, Jacques, Ellen Vos, and Luca Di Mauro (2000) "Reforming Product Regulation in the EU: A Painstaking, Iterative Two-Level Game” Chapter 7 in Regulatory Reform and Competitiveness in Europe Vol. 1, Giampaolo Galli and Jacques Pellmans (Eds), Edward Elgard Publishing, USA, pp.238-291.

Raballand, Gaël and Enrique Aldaz-Carroll (2005) "How Do Differing Standards Increase Trade Costs? The Case of Pallets", World Bank Policy Research Working Paper No. 3519. http://econ.worldbank.org/view.php?type=5\&id=41351

Swan, Peter, Paul Temple, and Mark Shurmer (1996) "Standards and Trade performance: The UK Experience”, The Economic Journal, 106 (September), pp. 1297-1313.

United States International Trade Commission (1998) “Global Assessment of Standards Barriers to Trade in the Information Technology Industry”. Publication 3141, November, Washington, DC.

Wilson, John S. (1995) Standards and APEC: An Action Agenda, Institute for International Economics, Washington, D.C

Wilson, John S. and Victor Abiola (2003) Standards and global trade: a voice for Africa, editors John S. Wilson and Victor O. Abiola, Washington, D.C. : World Bank.

Xiaoyang-Chen and Mattoo’s (2004) “Regionalism in standards: good or bad for trade?” World Bank Policy Research Working Paper No. 3458. 